\title{
Enrichment of table eggs with lutein
}

Obogaćivanje konzumnih jaja luteinom

Kralik, G., Kralik, Z., Grčević, M., Hanžek, D., Margeta, P., Galović, $\mathbf{O}$.

Poljoprivreda/Agriculture

ISSN: $1848-8080$ (Online)

ISSN: 1330-7142 (Print)

http://dx.doi.org/10.18047/poljo.26.1.8

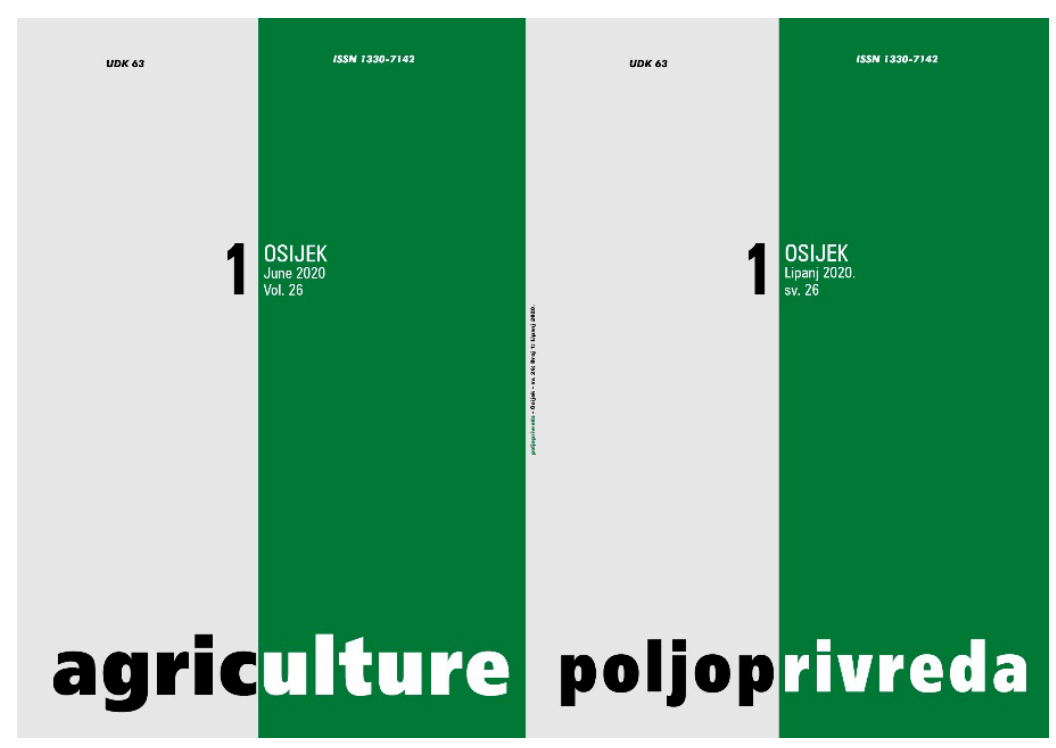

Fakultet agrobiotehničkih znanosti Osijek, Poljoprivredni institut Osijek

Faculty of Agrobiotechnical Sciences Osijek, Agricultural Institute Osijek 
ISSN $1330-7142$

UDK $=637.482$

DOI: $10.18047 /$ poljo.26.1.8

\title{
ENRICHMENT OF TABLE EGGS WITH LUTEIN
}

Kralik, G. ${ }^{(1,2)}$, Kralik, Z. ${ }^{(1,3)}$, Grčević, M. ${ }^{(1,3)}$, Hanžek, D. ${ }^{(1,3)}$, Margeta, $P^{(1,3)}$, Galović, $0 .^{(1,4)}$

\author{
Original scientific paper
}

Izvorni znanstveni članak

\begin{abstract}
SUMMARY
For the enrichment of eggs with lutein, a marigold flower extract - MFE (Tagetes erecta $L$.) was used. The two groups of laying hens were involved in the study - the control group (C) and the experimental group (E), respectively. The laying hens of the control group were fed by the lutein-free mixture, while the laying hens' $E$ group consumed the mixture with the $3 \mathbf{~ g} / \mathbf{k g}$ of lutein. The laying hens' feeding lasted for 31 days, after which the quality of eggs (i.e., the shape index, egg weight and the egg main parts, shell strength and thickness, Haugh units - HU, egg white height, egg yolk color, egg white $\mathrm{pH}$, and the egg yolk pH), as well as the lutein content and Thiobarbituric Acid Reactive Substances (TBARS) values in egg yolks, were determined. The study results have demonstrated that the added MFE exerted an effect of thickness, weight, and eggshell proportion reduction $(P<0.001)$, as well as of the shell strength reduction $(P=0.014)$. It has also reduced the $H U$ value $(P=0.039)$ and has increased the egg white content, egg yolk color, and the egg yolks' lutein content $(P<0.001)$. A statistically significant difference in TBARS values was found between the fresh and the stored eggs in group $C$, as well as between the $C$ and $E$ groups in the fresh eggs $(P<0.05)$. Our results indicate that MFE is suitable for the enrichment of table eggs with lutein.
\end{abstract}

Keywords: marigold flower extract, lutein, egg yolk color, egg quality, TBARS values

\section{INTRODUCTION}

Lutein is a pigment that can be accumulated in egg yolks. Lutein has a significant role in the maintenance of normal eye function, and it acts as an antioxidant, absorbs blue light, and protects the eyes from macular degeneration. Lutein is a yellow pigment from the carotenoids (xanthophylls) group. As the people cannot synthesize lutein, it has been consumed by diet and various supplements. Marigold flower (Tagetes erecta L.) is a plant rich in lutein that neutralizes free radicals in the body and protects the eyes from ultraviolet radiation. According to Šivel et al. (2014), this preparation comes to the market in the form of a concentrate $(50-265 \mathrm{mg} / \mathrm{g}$ of dry matter) or powder (54.2-802.3 mg/g DM), while Lokaewmanee et al. (2011) state that a more intense pigmentation of egg yolks is achieved by the usage of marigold flower extract (MFE) than marigold flower meal (MFM). For a more intense yolk color, $30-40 \mathrm{mg} / \mathrm{kg}$ should be added to the feed, regardless of the fact whether the eggs are fresh or cooked. Niu et al. (2008) report an effec- tive usage of peppers in the feeding of laying hens and in the deposition of pigments in egg yolks. A dilemma of using the pepper or the MFM in an egg enrichment with lutein was experienced by Oliveira et al. (2017). The authors concluded that a pepper extract intensifies the egg yolk color and improves the egg quality, whereas the MFE reduces the eggshell quality. The consumers prefer to use the eggs with the natural rather than with the artificial pigments (Dufosse 2006). Skrivan et al. (2016) found that the usage of MFE at a concentration of $550 \mathrm{mg} / \mathrm{kg}$ feed had a positive effect on the egg yolk color intensity, on the enrichment of eggs with carotenoids, and on the increase

(1) Prof. Emer., Ph. D., Dr. h. c Gordana Kralik - Josip Juraj Strossmayer University of Osijek, Scientific Center of Excellence for Personalized Health Care, Trg sv. Trojstva 3, 31000 Osijek, Croatia (2) Nutricin j. d. o .o. Darda, Đure Đakovića 6, 31326 Darda, Croatia, (3) Assoc. Prof. Zlata Kralik (zlata. kralik@fazos.hr), Manuela Grčević, Ph. D., Danica Hanžek, M. Eng. Agr., Polonca Margeta, Ph. D. - Josip Juraj Strossmayer University of Osijek, Faculty of Agrobiotechnical Sciences Osijek, Vladimira Preloga 1, 31000 Osijek, Croatia, (4) Assist. Prof. Olivera Galović - Josip Juraj Strossmayer University of Osijek, Department of Chemistry, Ulica cara Hadrijana 8/A, 31000 Osijek, Croatia 
of an oxidative stability of the lipids during the egg storage. The authors noted that MFE is a more appropriate alternative supplement than the synthetic xantophylls. These statements are confirmed by the results of another research (Nain, 2011; Kralik et al., 2014, Englmaierová et al., 2018). Grčević et al. (2019) also state that a marigold flower extract is suitable for the improvement of oxidative stability of lipids $(0,1$ and $2 \mathrm{~g} / \mathrm{kg}$ food), a lutein content increase, and the achievement of a more intense egg yolk color. The aim of the study was to enrich the eggs with lutein by using a marigold flower extract in the feeding of laying hens. At the same time, the physicochemical properties of the lutein-enriched eggs were investigated, as well as the oxidative processes of lipids during the egg storage, in relation to the conventional eggs.

\section{MATERIAL AND METHODS}

\section{Laying hens and feed}

In the study, 72 laying hens of Tetra SL hybrids were used, which were 37 weeks old at the start of the experiment. Laying hens were divided into two groups (C-control group and the E-experimental group) and kept in the enriched cages ( 36 laying hens per group; three repetitions). Group $\mathrm{C}$ consumed the feed mixture without the addition of marigold flower extract, while 3 $\mathrm{g} / \mathrm{kg}$ marigold flower extract was added to the group $\mathrm{E}$ mixture. The mixtures were balanced on the basis of a 17-percent crude protein and 11.5 MJ/kg ME (Table 1).

\section{Table 1. The composition of laying hens' feed mixtures}

Tablica 1. Sastav smjesa za nesilice

\begin{tabular}{|l|r|r|}
\hline Ingredient - Sastojak (\%) & C group - Skupina C & E group - Skupina E \\
\hline Corn - Kukuruz Sojino brašno & 51.53 & 51.23 \\
Soybean meal - & 23.23 & 5.23 \\
Sunflower meal - Suncokretovo brašno & 5.00 & 1.03 \\
Lucerne - Lucerka & 1.03 & 0.50 \\
Fodder yeast - Stočni kvasac & 0.50 & 10.70 \\
Limestone - Vapnenac & 10.70 & 1.33 \\
Monocalcium phosphate - Monokalcijev fosfat & 1.33 & 0.33 \\
Salt - Sol & 0.33 & 0.15 \\
Methionine - Metionin & 0.15 & 5.00 \\
Soybean oil - Sojino ulje & 5.00 & 1.20 \\
Premix* - Premiks & 1.20 & 0.30 \\
Marigold flower extract - Ekstrakt cvijeta kadife & 0.00 & 100.00 \\
\hline Total & 100.00 & 17.07 \\
\hline \multicolumn{2}{|c|}{ Chemical analyses - Kemijske analize } & \\
\hline Crude protein - Sirove bjelančevine & & 7.47 \\
Crude fat - Sirove masti & & 9.83 \\
Crude fibers - Sirova vlaknina & & 11.50 \\
Crude ash - Sirovi pepeo & & \\
\hline ME, MJ/kg (calculated - izračunana) & & \\
\hline
\end{tabular}

C group = without MFE; E group = $3 \mathrm{~g} \mathrm{~kg}^{-1}$ MFE; *Premix: calcium 33\%, vit. A 833,340 I.U., vit. D 208,340 I.U., vit. E 8,350 mg, vit. $K_{3} 170 \mathrm{mg}$, vit. $\mathrm{B}_{1} 150 \mathrm{mg}$, vit. $B_{2} 375 \mathrm{mg}$, pantothenic acid $590 \mathrm{mg}$, niacin 2,100 mg, choline chloride $33,340 \mathrm{mg}$. vit. $B_{6} 200 \mathrm{mg}$, vit. $B_{12} 960 \mathrm{mcg}$, biotin 7,100 mcg, folic acid $70.5 \mathrm{mg}$. vit. C 1,900 $\mathrm{mg}$, iron 2,500 mg, copper $415 \mathrm{mg}$, zinc 5,200 mg, manganese $5,835 \mathrm{mg}$, iodine $75 \mathrm{mg}$, selenium-yeast $35 \mathrm{mg}$, antioxidant (Apo-ester $85 \mathrm{mg}$, canthaxanthin $250 \mathrm{mg}$ )

${ }^{* *}$ Reference methods applied to the chemical analysis of feed: HRN ISO 6496: 200; HRN EN ISO 5983-2: 2010; HRN EN ISO 6865: 2001. Changed according to the instructions from the manual FOSS Fiber Cap; HRN ISO 5984: 2004; HRN ISO 6492: 2001. Modified according to the instructions of the extraction system ANKOM XT15; RU-5.4.2-11 (internal method).

Feeding and watering of hens were ad libitum, and both groups of hens were in the same facility under the same microclimatic conditions during 16 daylight hours. The experimental part related to the feeding of laying hens with different feed mixtures lasted for 31 days. The laying hens' weights were determined at the beginning and at end of the experiment. The quantities of feed consumed were also measured, and egg production was determined. Subsequent to the feeding period with the mixtures of modified composition, the eggs were sampled to analyze their physicochemical properties, intensity of lipid oxidation, and the lutein content of the yolks.

\section{Egg quality indicators}

A total of 100 eggs, or 50 eggs per group, were used for a physicochemical property analysis. The eggs were those of the class L (egg weight 63-73 g). The eggs were analyzed a day subsequent to the collection ( $n=25$ per group). The following quality indicators were determined: shape index, the weight of the egg and its basic parts, its strength, and eggshell thickness, Haugh unit, egg white height, egg yolk color, egg white $\mathrm{pH}$ and the egg yolk ph. On the basis of weights of the basic egg parts, their proportions (\%) were calculated. The shape index was calculated from the measures of egg length and width according to the 
following formula: $10=$ egg length/egg width $* 100$. The egg length and width were measured using a digital thickness gauge, with a measuring range amounting to 0-300 mm/0-12" (Insize, USA). The egg weight was measured using a laboratory scale (Mettler Toledo, BBK 422-6 DXS). The shell thickness was measured using an electronic micrometer with a measuring range from $0.25 \mathrm{~mm}$ to $0.001 \mathrm{~mm}$ in the middle of the eggshell, and an average of two measurements was used (Insize, USA). The Eggshell Force Gauge Model-II automatic device (Robotmation Co., Ltd., Japan) was used for the eggshell strength measurement. The yolk color, Haugh units $(\mathrm{HJ})$, and egg white height were determined by an automatic device Egg Multi-Tester EMT-5200 (Robotmation Co., Ltd., Japan). The egg white and egg yolk $\mathrm{pH}$ values were measured by a $\mathrm{pH}$ meter MP 120 (model SevenEasy).

\section{Lutein content analysis}

For the analysis of lutein in egg yolks, 12 eggs, or six per group, were used. The yolk samples were prepared according to the Leeson and Caston's method (2004). Lutein in egg yolks was determined using the Shimadzu HPLC system by weighing $0.5 \mathrm{~g}$ of egg yolk in a test tube, overflowing it with $5 \mathrm{ml}$ of acetone and vigorously stirring on a vortex mixer for 30 seconds. The samples were left to stand in the dark for one hour. Subsequent to a rest and filtration through a $0.45 \mu \mathrm{m}$ membrane filter CHROMAFIL ${ }^{\circledR}$ Xtra CA-45/25 (MACHEREY-NAGEL GmbH\&Co. KG, Düren, Germany), 1 $\mathrm{ml}$ of acetone extract was transferred to the HPLC vials and gently evaporated by heating. The residue in the vial was dissolved by the addition of $1 \mathrm{ml}$ of hexane / ethyl acetate solution $(65: 35, v / v)$ and mixed on the vortex. The sample thus prepared was analyzed on a Viva C18 column $(5 \mu \mathrm{m}, 250 \times 4.6 \mathrm{~mm}$; RESTEK Corporation, Bellefonte, PA, USA). The mobile phase consisted of a mixture of methanol and tetrahydrofuran (THF) 9:1 (v/v). The flow rate was $1 \mathrm{ml} / \mathrm{min}$, the analysis time was 20 minutes, and the measurement wavelength was 450 $\mathrm{nm}$. The injection volume was $20 \mu \mathrm{l}$. The standard lutein curve was prepared using the lutein standard purchased from ChromaDex (Irvine, CA, USA).

\section{Lipid oxidation}

The oxidation of lipids in egg yolks of the fresh and stored eggs was determined using the TBARS value $(\mu \mathrm{g}$ MDA-malondialdehyde/g egg yolk). The samples were prepared as follows: $10 \%$ trichloroacetic acid was added to the weighed egg yolk, the mixture was homogenized and centrifuged at $5500 \mathrm{rpm}, 4^{\circ} \mathrm{C}$. Subsequent to the centrifugation, a solution of thiobarbituric acid $(\mathrm{pH} 2.5)$ was added to the supernatant, the tubes were closed and immersed in a water bath at $95^{\circ} \mathrm{C}$ for 30 minutes. Subsequent to the cooling, distilled water was added, and the mixture was centrifuged at $5500 \mathrm{rpm}, 4^{\circ} \mathrm{C}$. The content of the colored product formed by the reaction of lipid peroxidation products with thiobarbituric acid was measured spectrophotometrically at $534 \mathrm{~nm}$. The obtained values were compared with the standard curve prepared using the standard malondialdehyde tetrabutylammonium salt (Sigma-Aldrich, Switzerland) and expressed in $\mu \mathrm{g}$ $\mathrm{MDA} / \mathrm{g}$ of egg yolk. For the purpose of oxidation determination, 20 eggs were used (10 per group).

\section{Statistical analisys}

The research results were processed using the TIBC Statistica ${ }^{\mathrm{TM}}$ version 13.4.0.14. (Soft Inc. ${ }^{\odot} 1984-2018$ ). Descriptive statistics and an analysis of variance were performed (ANOVA). If the $P$ value for the analysis of variance was statistically significant, the differences between the groups were tested by the Fisher LSD test $(\mathrm{P}<0.05 ; \mathrm{P}<0.01 ; \mathrm{P}<0.001)$.

\section{RESULTS AND DISCUSSION}

The weights of laying hens, consumption, and conversion of feed as well as egg production are shown in Table 2. Group $C$ during the 31 days of the study increased the average body weight by $38 \mathrm{~g}(\mathrm{P}>0.05)$, while the $E$ group of laying hens reduced the average weight by $61 \mathrm{~g}(\mathrm{P}<0.05)$. The average daily consumption of feed mixture in group $C$ laying hens was $116.00 \pm 3.09 \mathrm{~g}$, while in group $\mathrm{E}$ was $121.17 \pm 3.10 \mathrm{~g}$, respectively. Egg production in both groups of laying hens was equal ( 80.0 and $80.5 \%$ ), and $145.33 \pm 3.76 \mathrm{~g}$ or $150.33 \pm 3.77 \mathrm{~g}$ of the feed mixture was consumed per egg $(P>0.05)$.

Table 2. The laying hens' performances during the experiment

Tablica 2. Performance kokoši nesilica tijekom pokusa

\begin{tabular}{|l|c|c|}
\hline $\begin{array}{l}\text { Indicator } \\
\text { Pokazatelj }\end{array}$ & $\begin{array}{c}\text { C group } \\
\text { (Mean } \pm \text { SE) }\end{array}$ & $\begin{array}{c}\text { E group } \\
\text { (Mean } \pm \text { SE) }\end{array}$ \\
\hline $\begin{array}{l}\text { Weight of the laying hens at the beginning of the experiment (g) } \\
\text { Masa kokoši nesilica na početku pokusa (g) }\end{array}$ & $1948.94 \pm 104.97$ & $1986.94 \pm 122.54$ \\
\hline $\begin{array}{l}\text { Weight of the laying hens at the end of the experiment (g) } \\
\text { Masa kokoši na kraju pokusa (g) }\end{array}$ & $1997.88 \pm 127.47^{\mathrm{a}}$ & $1936.72 \pm 128.63^{\mathrm{b}}$ \\
\hline $\begin{array}{l}\text { Feed consumption (g/day) } \\
\text { Konzumacija hrane (g/dan) }\end{array}$ & $116.00 \pm 3,09$ & $121.17 \pm 3.10$ \\
\hline $\begin{array}{l}\text { Feed conversion (g/egg) } \\
\text { Konverzija hrane (g/jaje) }\end{array}$ & $145.33 \pm 3,76$ & $150.33 \pm 3.76$ \\
\hline $\begin{array}{l}\text { Egg production } \\
\text { Proizvodnja jaja (\%) }\end{array}$ & $80.00 \pm 2,95$ & 0.140 \\
\hline
\end{tabular}

$\mathrm{C}$ group = without MFE; E group = added MFE $3 \mathrm{~g} / \mathrm{kg}$ feed; ${ }^{\mathrm{a}, \mathrm{b} P}<0.05$ 
The results of our research are in agreement with those reported by Antunas and Aydin (2014) regarding daily consumption of the feed mixture and the performance of the laying hens.

Skrivan et al. (2016) examined the effect of MFE (0; 150; 350; 550; 750 and $950 \mathrm{mg} / \mathrm{kg}$ ) in feed for laying hens on egg production and quality. They found that MFE had no effect on laying hens body weight, feed conversion, and egg quality. However, higher concentrations of MFE influenced increased egg production, egg weight $(P<0.01)$ and the mixture intake $(P<0.05)$. Antunas and Aydin (2014) found no effect of MFE on egg production and egg quality indicators.

The physicochemical characteristics of the $C$ and E group eggs and the weight of the basic parts are figured in Table 3. There were no statistically significant differences in the shape index, egg white, and egg yolk weight $(P>0.05)$. The research data demonstrate that the lutein added to the laying hen feed mixture affect the eggshell quality indicators. The laying hens of the experimental group produced the eggs with a thinner and lighter shell $(\mathrm{P}<0.001)$ and the eggs with a lower shell strength $(P=0.014)$ compared to the control group of laying hens. Although a statistically significant difference was found between the control and experimental groups in shell thickness, the obtained values are in the optimal interval for egg handling and transport. Petričević et al. (2017) determined an eggshell thickness of $0.313 \mathrm{~mm}$ in laying hens of Tetra SL hybrid at the age of 45 weeks, which is less than our result. A higher egg white and the lower egg shell proportions $(P<0.001)$ were found in the eggs of the laying hens' experimental group when compared to the control group, whereas there was no difference between groups in the egg yolks proportions $(P>0.05)$. In the study of Oliveira et al. (2017), it was found that the MFE reduced the percentage of shell $(P<0.02)$, as well as the shell thickness $(P<0.001)$. The similar results were obtained by Roberts (2004). Sharoni et al. (2012), Veprik et al. (2012), and Zhang et al. (2012) found that lutein and zeaxanthin inhibit an estrogenic activity in some tissues, which was probably the case with the shell formation in our study.

Table 3. Eggshell quality and the weight of the basic fresh egg parts

Table 3. Kvaliteta ljuske i mase osnovnih dijelova svježih jaja

\begin{tabular}{|c|c|c|c|}
\hline $\begin{array}{l}\text { Indicators } \\
\text { Pokazatelji }\end{array}$ & $\begin{array}{c}C \text { group }(n=25) \\
\text { Mean } \pm S E\end{array}$ & $\begin{array}{c}\text { E group }(n=25) \\
\text { Mean } \pm S E\end{array}$ & $\begin{array}{c}\mathrm{P} \text { value } \\
P \text { vrijednost }\end{array}$ \\
\hline $\begin{array}{l}\text { Shape index, \% } \\
\text { Indeks oblika, \% }\end{array}$ & $76.44 \pm 3.48$ & $75.16 \pm 3,04$ & 0.173 \\
\hline $\begin{array}{l}\text { Shell thickness, mm } \\
\text { Debljina ljuske, } m m\end{array}$ & $0.44 \pm 0.03^{A}$ & $0.40 \pm 0,04^{B}$ & 0.001 \\
\hline $\begin{array}{l}\text { Shell strength, } \mathrm{kg} / \mathrm{cm}^{2} \\
\text { Čvrstoća ljuske, } \mathrm{kg} / \mathrm{cm}^{2}\end{array}$ & $3.09 \pm 0.65^{a}$ & $2.71 \pm 0.36^{b}$ & 0.014 \\
\hline $\begin{array}{l}\text { Egg weight, } g \\
\text { Masa jajeta, } g\end{array}$ & $65.43 \pm 2.93$ & $65.46 \pm 2.98$ & 0.969 \\
\hline $\begin{array}{l}\text { Egg white weight, g } \\
\text { Masa bjelanjka, } g\end{array}$ & $39.54 \pm 2.62$ & $40.93 \pm 2,58$ & 0.063 \\
\hline $\begin{array}{l}\text { Egg white share, } \% \\
\text { Udio bjelanjka, \% }\end{array}$ & $60.39 \pm 1.84^{B}$ & $62.51 \pm 2.03^{\mathrm{A}}$ & 0.001 \\
\hline $\begin{array}{l}\text { Egg yolk weight, g } \\
\text { Masa žumanjka, } g\end{array}$ & $17.34 \pm 1.04$ & $17.11 \pm 1,28$ & 0.473 \\
\hline $\begin{array}{l}\text { Egg yolk share, } \% \\
\text { Udio žumanjka, \% }\end{array}$ & $26.53 \pm 1.49$ & $16.14 \pm 1.84$ & 0.423 \\
\hline $\begin{array}{l}\text { Shell weight, g } \\
\text { Masa ljuske, } g\end{array}$ & $8.54 \pm 0.46^{A}$ & $7.42 \pm 0.57^{\mathrm{B}}$ & 0.001 \\
\hline $\begin{array}{l}\text { Egg shell share, \% } \\
\text { Udio ljuske, \% }\end{array}$ & $13.07 \pm 0.81^{\mathrm{A}}$ & $11.34 \pm 0.88^{B}$ & 0.001 \\
\hline
\end{tabular}

$\mathrm{C}$ group = without MFE; E group = added MFE $3 \mathrm{~g} / \mathrm{kg}$ feed; ${ }^{\mathrm{a}, \mathrm{b} P}<0.05 ;{ }^{\mathrm{A}, \mathrm{B}} \mathrm{P}<0.001$

Table 4 demonstrates the results of an internal egg quality study and the lutein content of egg yolks. The eggs of the laying hens' control group had a higher egg white height and a higher egg yolk $\mathrm{pH}$ than the eggs of the $E$ group, but the differences were not statistically significant $(P>0.05)$. The higher Haugh units were found in the $C$ group eggs $(P=0.039)$, as was a more intense egg yolk color $(\mathrm{P}<0.01)$ in the eggs of the laying hens' $E$ group. The difference in lutein content between the laying hens' $C$ and $E$ groups was also significant. A determined lutein content was 9.91 times higher in the egg yolks of the group $E$ than in the egg yolks of the group C $(\mathrm{P}<0.01)$. 
Table 4. Internal quality indicators and the lutein content in the fresh egg yolks

Tablica 4. Pokazatelji unutarnje kvalitete i sadržaj luteina u svježim jajima

\begin{tabular}{|c|c|c|c|}
\hline $\begin{array}{l}\text { Indicators } \\
\text { Pokazatelji }\end{array}$ & $\begin{array}{l}C \text { group }(n=25) \\
\text { Mean } \pm S E\end{array}$ & $\begin{array}{l}\text { E group }(n=25) \\
\text { Mean } \pm S E\end{array}$ & $\begin{array}{c}\text { P value } \\
P \text { vrijednost }\end{array}$ \\
\hline $\begin{array}{l}\text { Egg white height, mm } \\
\text { Visina bjelanjka, } \mathrm{mm}\end{array}$ & $6.46 \pm 1.04$ & $6.18 \pm 0.81$ & 0.287 \\
\hline HU & $77.56 \pm 5.94^{\mathrm{a}}$ & $73.50 \pm 7.53^{b}$ & 0.039 \\
\hline $\begin{array}{l}\text { Egg yolk color } \\
\text { Boja žumanjka }\end{array}$ & $12.24 \pm 0.87^{B}$ & $13.88 \pm 0.33^{A}$ & 0.001 \\
\hline $\begin{array}{l}\text { Egg white } \mathrm{pH} \text { value } \\
\text { pH vrijednost bjelanjka }\end{array}$ & $8.49 \pm 0.21$ & $8.54 \pm 0.27$ & 0.508 \\
\hline $\begin{array}{l}\text { Eqq yolk pH value } \\
\text { pH vrijednost žumanjka }\end{array}$ & $6.01 \pm 0.07$ & $5.98 \pm 0.09$ & 0.251 \\
\hline $\begin{array}{l}\text { Lutein content, mg/100 g of yolk } \\
\text { Sadržaj luteina, mg/100 g žumanjka }\end{array}$ & $0.72 \pm 0.11^{B}$ & $7.14 \pm 0.72^{\mathrm{A}}$ & 0.001 \\
\hline
\end{tabular}

$\mathrm{C}$ group $=$ without MFE; $\mathrm{E}$ group $=$ added MFE $3 \mathrm{~g} / \mathrm{kg}$ feed; ${ }^{\mathrm{a}, \mathrm{b}} \mathrm{P}<0.05 ;{ }^{\mathrm{A}}, \mathrm{B} \mathrm{P}<0.001$

Oliveira et al. (2017) used a MFE (1 g/kg food) and pepper extract ( $56 \mathrm{~g} / \mathrm{kg}$ food) in the egg enrichment with lutein. The ingredients added did not affect the weight of the eggs, the Haugh units, or the amount of eggs produced. The pepper extract lowered the $\mathrm{pH}$ of the egg white. Marigold flower extract in the laying hens' feed influenced the reduction of proportion $(P<0.02)$ and thickness $(\mathrm{P}<0.01)$ of the eggshell, which was also the case in our study. Kralik et al. (2017) determined a yolk color of 12.80 in the market eggs. Given that the authors measured the yolk color in the eggs stored for seven days at $4^{\circ} \mathrm{C}$, the values are slightly higher than the yolk color of our Control group (12.24). Yan et al. (2014) stated that the addition of low concentrations of lutein to the laying hens' feed $(40 \mathrm{mg} / \mathrm{kg})$ affected the yolk color $(P<0.05)$. Lokaewmanee et al. (2011) found an increase in the $\mathrm{CIE} \mathrm{a}^{*}$ value $(\mathrm{P}<0.05)$ and a decrease in CIE $L^{*}$ value $(P>0.05$ in the assessment of the egg yolk color when lutein was added $10-40 \mathrm{~g} / \mathrm{kg}$ food. Sirri et al. (2007) found that an increase in lutein of 80-100 $\mathrm{mg} / \mathrm{kg}$ of the mixture only affects the increase of the $a^{*}$ value, and has no effect on the $b^{*}$ and $L^{*}$ values, which is in agreement with the results of Englmaierová et al. (2013), as well as with those by Grčević et al. (2018). Lokaewmanee et al. (2011) added the marigold flower meal lutein to the laying hens' mixtures and the MFE lutein in amounts of $10,20,30$ and $40 \mathrm{mg} / \mathrm{kg}$, and found, using the Roche scale, that the best pigmentation effect was achieved at $40 \mathrm{mg} / \mathrm{kg}$ MFM and 20, 30 and $40 \mathrm{mg} /$ $\mathrm{kg}$ of MFE. They recommend the usage of $30-40 \mathrm{mg} / \mathrm{kg}$ of
MFE because a saponified lutein is more effective in the coloring of egg yolks than the lutein from the MFM. The authors find that xanthophylls from the MFE, which are esterified with fatty acids, are more easily absorbed in the laying hens' digestive tract. The MFE lutein is transported more rapidly through the intestines and deposits faster in yolks than an unsaponified lutein (Galobart et al. 2004). Lokaewmanee et al. (2011) also agreed with this statement. Šivel et al. (2014) reported that there was a difference in the lutein content (mg 100/g DM) in the samples of marigold flower concentrates (56.8-272) and in the marigold flower powder (55-802.3), respectively, and therefore the different results were obtained in the egg enrichment with lutein. Our results are in agreement with those by Grčević et al. (2018), as well as with those by Lokaewmanee et al. (2011), circumstantiating that MFE can successfully enrich the eggs with lutein if added to the laying hens' diet.

Table 5 figures the TBARS values in egg yolks from the $C$ and $E$ groups $(P=0.014)$ in the fresh eggs. The differences in the stored eggs between the $C$ and $E$ groups were not statistically significant $(C=1.08$ and $\mathrm{E}=0.94 \mu \mathrm{g} \mathrm{MDA} / \mathrm{g} ; \mathrm{P}=0.085)$. When observing the lipid oxidation processes within the Group $\mathrm{C}$, a statistically significant difference in the TBARS values was found between the fresh and the stored eggs $(0.89: 1.08 \mu \mathrm{g}$ $\mathrm{MDA} / \mathrm{g} ; \mathrm{P}=0.026)$. Although the value of TBARS in the $\mathrm{E}$ group in the stored eggs is lower $(0.94 \mu \mathrm{g} \mathrm{MDA} / \mathrm{g})$ than the one in the fresh eggs $(1.02 \mu \mathrm{g} \mathrm{MDA} / \mathrm{g})$, the difference is not statistically significant $(\mathrm{P}=0.093)$. 
Table 5. TBARS values ( $\mu \mathrm{g} \mathrm{MDA} / \mathrm{g}$ egg yolk)

Tablica 5. TBARS vrijednosti ( $\mu g$ MDA/g žumanjka)

\begin{tabular}{|l|c|c|c|}
\hline $\begin{array}{l}\text { Group/Analysis time } \\
\text { Skupina/Vrijeme analize }\end{array}$ & $\begin{array}{c}\text { C group }(\mathrm{n}=5) \\
\text { (mean } \pm \text { SE) }\end{array}$ & $\begin{array}{c}\text { E group }(\mathrm{n}=5) \\
\text { (mean } \pm \text { SE) }\end{array}$ & $\begin{array}{c}\text { P value } \\
\text { P vrijednost }\end{array}$ \\
\hline $\begin{array}{l}\text { Fresh egg } \\
\text { Svježa jaja }\end{array}$ & $0.89 \pm 0.03^{\mathrm{a}, \mathrm{x}}$ & $1.02 \pm 0.10^{\mathrm{b}}$ & 0.014 \\
\hline $\begin{array}{l}\text { Stored egg } \\
\text { Skladištena jaja }\end{array}$ & $1.08 \pm 0.11^{\mathrm{y}}$ & $0.94 \pm 0.08$ & 0.085 \\
\hline $\begin{array}{l}\text { P value } \\
\text { P vrijednost }\end{array}$ & 0.026 & 0.093 & - \\
\hline
\end{tabular}

$\mathrm{C}$ group = without MFE; $\mathrm{E}$ group = added MFE $3 \mathrm{~g} / \mathrm{kg}$ of feed; ${ }^{a, b}, \mathrm{x}, \mathrm{yP}<0.05 ;{ }^{a, b}$ letters above numbers represent the difference between the values shown in the rows; $x, y$ letters above numbers represent the difference between the values shown in the columns

Grčević et al. (2019), as well as Kralik et al. (2018), have reported that MFE has an effect on the oxidative stability of eggs during storage. Akter et al. (2014) found the TBARS values similar to our results subsequent to the 28 days of egg storage. Englmaierová et al. (2013) also state that lutein enhances an oxidative stability of eggs. The authors added $250 \mathrm{mg} / \mathrm{kg}$ of lutein to the mixtures and found 1.17 and $0.87 \mathrm{mg}$ of MDA/ $\mathrm{kg}$ in the fresh eggs from the control and experimental groups, respectively, and 1.28 and $1.04 \mathrm{mg}$ of $\mathrm{MDA} / \mathrm{kg}$ of egg yolk after 28 days of storage.

\section{CONCLUSION}

Based on our study results, it can be concluded that the addition of MFE $3 \mathrm{~g} / \mathrm{kg}$ to the laying hens' feed significantly affects the increase in lutein content in the egg yolks $(7.14 \pm 0.12 \mathrm{mg} / 100 \mathrm{~g})$ when compared to the Control group $(0.72 \pm 0.11 \mathrm{mg} / 100 \mathrm{~g})$, which is an increase of 9.91 times $(\mathrm{P}<0.01)$. The added MFE in the mixture increases the egg white content of the egg and intensifies the yolk color, but it decreases the quality of shell. A statistically significant difference in the TBARS values was found between the fresh and the stored eggs (0.89: $1.08 \mu \mathrm{g} \mathrm{MDA} / \mathrm{g} ; \mathrm{P}=0.026$ ) in the $\mathrm{C}$ group and between the $C$ and $E$ groups in the fresh eggs (0.89: $1.02 \mu \mathrm{g} \mathrm{MDA} / \mathrm{g} ; \mathrm{P}=0.014$ ). It also improves the oxidative stability of lipids in eggs during their storage. Using the MFE in the laying hens' feed, the eggs can be effectively enriched with lutein and declared a functional product.

\section{ACKNOWLEDGEMENT}

This study is supported by the European Structural and Investment Funds grant for the Croatian National Scientific Center of Excellence for Personalized Health Care (grant \#KK.01.1.1.01.0010) and by Ministry of Science and Education of the Republic of Croatia.

\section{REFERENCES}

1. Akter, Y., Kasim, A., Omar, H. \& Sazili A. 0. (2014). Effect of storage time and temperature on the quality characteristics of chicken eggs. Journal of Food, Agriculture and Environment, 12(2): 87-92.

2. Altuntaş, A. \& Aydin, R. 2014. Fatty acid composition of egg yolk from chickens fed a diet including Marigold (Tagetes erecta L.). Journal of Lipids, 1-4, http://dx.doi.org/10.1155/2014/564851

3. Dufossé, L. 2006. Microbial production of food grade pigments. Food Technology and Biotechnology, 44(3): 313-323.

4. Englmaierová, M., Skřivan, M. \& Bubancová, I. (2013). A comparison of lutein, sprey-dried chlorella, and synthetic carotenoids effects on yolk colour, oxidative stability, and reproductive performance of laying hens. Chech Journal of Animal Science, 58(9): 412-419.

5. Galobart, J., Sala, R., Rincón-Carruyo, X., Manzanilla, E.G., Vila, B. \& Gasa, J. (2004). Egg yolk color as affected by saponification of different natural pigmenting sources. Journal of Applied Poultry Research, 13(2): 328-334. http://dx.doi.org/10.1093/japr/13.2.328

6. Grčević, M., Kralik, Z., Kralik G. \& Galović, 0. (2018). Effects of dietary marigold extract on lutein content, yolk color and fatty acids profile of omega-3 eggs. Journal of the Science of Food and Agriculture, 99(5): 2292-2299. http://dx.doi.org 10.1002/jsfa.9425

7. Grčević, M., Kralik, Z., Kralik, G., Galović, D., Radišić, Ž. \& Hanžek, D. (2019). Quality and oxidative stability of eggs laid by hens fed marigold extract supplemented diet. Poultry Science, 98: 3338-3344. http://dx.doi.org/10.3382/ps/pez134

8. Kralik, Z., Grčević, M., Kralik, G., Hanžek, D. \& Zelić, A. (2017). Quality of table eggs on the Croatian market. Poljoprivreda, 23(1): 63-68. http://dx.doi.org/10.18047/poljo.23.1.10

9. Kralik, G., Kralik, Z., Grčević, M., Kralik, I. \& Gantner, V. (2018). Enrichment of table eggs with functional ingredients. Journal of Central European Agriculture, 19(1): 72-82. https://doi.org/10.5513/JCEA01/19.1.2025 
10. Kralik, Z., Kralik, G., Grčević, M. \& Galović, D. (2014). Effect of storage period on the quality of table eggs. Acta Agraria Kaposváriensis, 18(1): 200-206.

11. Leeson, S. \& Caston, L. (2004). Enrichment of eggs with lutein. Poultry Science, 83(10): 1709-1712. https://doi.org/10.1093/ps/83.10.1709

12. Lokaewmance, K., Yamauchi, K., Komori, T. \& Saito, K. (2011). Enhancement of yolk color and boiled egg yolk with lutein from marigold flower meal and marigold flower extract. Journal of Poultry Science, 48(1): 25-32. https://doi.org/10.2141/jpsa.010059

13. Nain, S. (2011). Improving the effectiveness of laying hens for use in value-added egg production. MSc thesis, Department of Agricultural, Food and Nutritional Science, University of Alberta, Canada.

14. Niu, Z., Fu, J., Gao, Y. \& Liu, F. (2008). Influence of paprika extract supplement on egg quality of laying hens fed wheat-based diet. International Journal of Poultry Science, 7(9): 887-889. https://doi.org/10.3923/ijps.2008.887.889

15. Oliveira, M. C. D., Silva, W. D. D., Oliveira, H. C., Moreira, E. D. O. B., Gomes, Y. D. S. \& Souza Junior, M. A. P. D. (2017). Paprika and/or marigold extracts in diets for laying hens. Revista Brasileira de Saúde e Produção Animal, 18(2), 293-302. https://doi.org/10.1590/s1519-99402017000200008

16. Petričević, V., Škrbić, Z., Lukić, M., Petričević, M., Dosković, V., Rakonjac, S., \& Marinković, M. (2017). Effect of genotype and age of laying hens on the quality of eggs and egg shells. Scientific Papers-Series D-Animal Science, 60, 166-170.

17. Roberts, J. R. (2004). Factors affecting egg internal quality and egg shell quality in laying hens. The Journal of Poultry Science, 41(3): 161-177. https://doi.org/10.2141/jpsa.41.161

18. Sharoni, Y., Linnewiel-Hermoni, K., Zango, G., Khanin, M., Salman, H., Veprik, A., ... \& Levy, J. (2012). The role of lycopene and its derivatives in the regulation of transcription systems: implications for cancer prevention. The American Journal of Clinical Nutrition, 96(5) 1173S-1178S. https://doi.org/10.3945/ajcn.112.034645

19. Sirri, F., laffaldano, N., Minelli, G., Meluzzi, A., Rosato, M. P. \& Franchini, A. (2007). Comparative pigmentation efficiency of high dietary levels of apo-ester and marigold extract on quality traits of whole liquid egg of two strains of laying hens. Journal of Applied Poultry Research, 16(3): 429-437.

https://doi.org/10.1093/japr/16.3.429

20. Skřivan, M., Marounek, M., Englmaierová, M. \& Skřivanová, E. (2016). Effect of increasing doses of marigold (Tagetes erecta) flower extract on eggs carotenoids content, colour and oxidative stability. Journal of Animal and Feed Sciences, 25: 58-64. https://doi.org/10.22358/jafs/65588/2016

21. Šivel, M., Kračmar, S., Fišera, M., Klejdus, B. \& Kuban, V. (2014). Lutein content of marigold flower (Tagetes erecta L.) concentrates used for production of food supplements. Czech Journal of Food Sciences, 32(6): 521-525. https://doi.org/10.17221/104/2014-CJFS

22. Veprik, A., Khanin, M., Linnewiel-Hermoni, K., Danilenko, M., Levy, J. \& Sharoni, Y. (2011). Polyphenols, isothiocyanates, and carotenoid derivatives enhance estrogenic activity in bone cells but inhibit it in breast cancer cells. American Journal of Physiology-Endocrinology and Metabolism, 303(7), E815-E824. https://doi.org/10.1152/ajpendo.00142.2011

23. Yan, Y. Y., Sun, C. J., Zheng, J. X., Xu, G. Y. \& Yang, N. (2014). Effect of uniformity of eggshell thickness on eggshell quality in chickens. Journal of Poultry Science, 51(3), 338-342. https://doi:10.2141/jpsa.0130032

24. Zhang, X., Spiegelman, D., Baglietto, L., Bernstein, L., Boggs, D. A., Van Den Brandt, P. A., ... \& Goodman, G. (2012). Carotenoid intakes and risk of breast cancer defined by estrogen receptor and progesterone receptor status: a pooled analysis of 18 prospective cohort studies. The American Journal of Clinical Nutrition, 95(3), 713-725. https://doi.org/10.3945/ajcn.111.014415 


\section{OBOGAĆIVANJE \\ KONZUMNIH JAJA LUTEINOM}

\section{SAŽETAK}

U svrhu obogaćivanja jaja luteinom, upotrijebljen je Marigold Flower Extract - MFE (ekstrakt cvijeta kadife Tagetes erecta L.). U istraživanju su korištene dvije skupine nesilica - kontrolna (C) i pokusna (E). Kontrolna skupina nesilica hranjena je smjesom bez dodatka luteina, dok su nesilice $E$ skupine konzumirale smjesu $\mathbf{s} 3$ g/kg luteina. Hranidba nesilica trajala je 31 dan, nakon čega je obavljena analiza kvalitete jaja (indeks oblika, masa jaja i osnovnih dijelova u jajetu, čvrstoća i debljina ljuske, Haugh jedinice - HU, visina bjelanjka, boja žumanjka, pH bjelanjka i pH žumanjka), te je utvrđen sadržaj luteina i TBARS (Thiobarbituric Acid Reactive Substances) vrijednosti u žumanjcima. Rezultati istraživanja pokazali su da dodani MFE utječe na smanjenje debljine, težine $i$ udjela ljuske $(P<0,001)$, odnosno na smanjenje čvrstoće ljuske $(P=0,014)$. Također, on utječe na smanjenje vrijednosti $H U(P=0,039)$, a povećava udjele bjelanjka, boju žumanjka i sadržaj luteina u žumanjcima jaja $(P<0,001)$. Statistički značajna razlika u vrijednostima TBARS-a utvrđena je između svježih $i$ čuvanih jaja kod C skupine, kao i između C i E skupina kod svježih jaja $(P<0,05)$. Naši rezultati ukazuju da je MFE pogodan za obogaćivanje konzumnih jaja luteinom.

Ključne riječi: ekstrakt cvijeta kadife, lutein, boja žumanjka, kvaliteta jaja, TBARS vrijednosti

(Received on January 21, 2020; accepted on May 13, 2020 - Primljeno 21. siječnja 2020.; prihvaćeno 13. svibnja 2020.) 